\title{
THE FALSE DMITRY AND JAMES THE OLD PRETENDER: MARY PIX'S THE CZAR OF MUSCOVY*
}

\author{
Samia Al-Shayban \\ King Saud University, \\ Riyadh, Saudi Arabia
}

The British dramatist Mary Pix’s (1666-1709) play The Czar of Muscovy (1701) has received limited and inconsistent critical attention compared to her other plays. This paper offers a fresh analysis of the play, which depicts the rule of the Russian pretender Dmitry Ivanovic, which lasted from 1605 to 1606 when he was killed in an uprising. The reading centralizes the history of false Dmitry during the Time of Troubles and his dramatic role as a figurative representation of the English Catholic pretender James Edward Francis Stuart (James the Old Pretender). Pix manipulates the public and private image of the False Dmitry (called Demetrius in the play) to undermine the Catholic pretender James' claim to the English throne. This can be seen through a comparison of their public image and similar biographical details. Demetrius' private image displays his tyranny and effeminacy, which are exposed through his treatment of the key women in his life: Queen Marina, his supposed mother Empress Sophia, and his captive Zarriana. In their own ways, the three women help him to reach the throne only to destroy him. Their dramatization as powerful agents who face oppression and achieve triumph is a message to Pix's female audience to emulate the female characters and prevent the restoration of the pretender. Thus, Russian history emerges as a dynamic and unifying force that transcends time and geography.

Keywords: Mary Pix, $17^{\text {th }}$-century Russia, $17^{\text {th }}$-century England, pretenders, Time of Trouble

Пьеса «Царь Московии» (1701) британского драматурга Мэри Пикс (16661709) не получила достаточного освещения в литературоведении, в отличие от других ее произведений. Настоящая статья предлагает новый подход к анализу пьесы, которая повествует о правлении самозванца Дмитрия I Ивановича (1605-1606), убитого в результате мятежа. Произведение сосредоточено вокруг Лжедмитрия I, Смутного времени и драматической

* Citation: Al-Shayban, S. (2021). The False Dmitry and James the Old Pretender: Mary Pix’s The Czar of Muscovy. In Quaestio Rossica. Vol. 9, № 2. P. 647-665. DOI 10.15826/qr.2021.2.601.

Цитирование: Al-Shayban S. The False Dmitry and James the Old Pretender: Mary Pix’s The Czar of Muscovy // Quaestio Rossica. Vol. 9. 2021. № 2. P. 647-665. DOI 10.15826/qr.2021.2.601. 
роли главного героя как метафорической параллели католика Джеймса Фрэнсиса Эдуарда Стюарта (Джеймса Старого Претендента). Пикс манипулирует общественным и личным образом Лжедмитрия I, чтобы достичь другой цели - подорвать попытки Джеймса Старого Претендента захватить английский трон: сюжет следует воспринимать через сопоставление публичных образов русского и английского самозванцев, которые обладают существенным сходством. Образу Лжедмитрия свойственны женоподобие и склонность к тирании, проявляющиеся в том, как он обращается с женщинами, сыгравшими ключевую роль в его жизни, - царицей Марией, его предполагаемой матерью императрицей Софией и пленницей Зарряной. Каждая из них помогает ему достичь цели и взойти на престол, только чтобы в итоге его уничтожить. Обращаясь к своей женской аудитории и побуждая ее не допустить восстановления самозванца на престоле, автор пьесы изображает этих героинь как могущественных персонажей, сталкивающихся с угнетением, но побеждающих. Можно сделать вывод, что русская история выступает в пьесе в качестве динамической объединяющей силы, которая преодолевает границы времени и географии.

Ключевые слова: Мэри Пикс, Россия XVII в., Англия XVII в., самозванцы, Смутное время

The British dramatist Mary Pix (1666-1709), one of the most popular and successful dramatists of her era, has been critically overlooked and misread in the relevant literature. During her lifetime, she was subjected to "frequent misogynistic lampoons on her supposed ignorance" [Finberg, p. XIII]. In the anonymous satire The Female Wits (1696), which attacked the female dramatists of the Restoration, Pix was ridiculed as "Mrs Wellfed", a fat dramatist who is open-hearted yet foolish and ignorant. For Laurie Finke, The Female Wits "does not merely satirize women playwrights; it seeks to deny them authority... to author texts" [Finke, p. 66]. This approach affected Mary Pix's critical standpoint as a female dramatist of the Restoration and late Stuart eras. Finberg notes that Pix "played an important role in the theatrical history of Restoration and eighteenthcentury England." This fact "has been forgotten or ignored for" hundreds of years [Finberg, p. IX]. The Czar of Muscovy, which premiered in 1701, is a good example of Pix's critical marginalization and misinterpretation. The play depicts the reign of the False Dmitry (called in the play as Demetrius) and his consort Marina Mniszech. In the play, he claims to be the youngest son of the late tsar Ivan IV Vasilyevich (1547-1575). He is crowned, but in a short space of time dethroned and subsequently murdered.

The play has received mixed critical attention; it is either completely ignored or misread. Claudine Van Hensbergen and Jose Yebra argue that despite growing interest in Pix's plays, she has failed to attract critical recognition that corresponds to the value of her plays and the popularity she enjoyed during her lifetime [Hensbergen, p. 89; Yebra, p. 150]. Pilar Cuder-Dominguez stresses that "despite... worthy efforts" to highlight the 
works of Mary Pix, she, like other female author of her era, remains on the "periphery of all major studies of seventeenth-century" and eighteenthcentury drama [Cuder-Dominguez, p. 2]. Surprisingly, Cuder-Dominguez contradicts herself and chooses to overlook The Czar of Muscovy [Ibid., p. 83-101] when discussing some of Pix's plays. Dominguez is not alone in ignoring the play, however. Bridget Orr examines Restoration and eighteenth-century plays that employ an "historical imaginary in which local political problems... could be... explored and resolved" [Orr, 2001, p. 61]. Orr highlights the dramatic and political importance of the Levant, the Orient, and the Far East. Despite its geographical diversity, she refrains from pinpointing Russia, a unique geographical location with a rich and complex political and historical fabric [Ibid., p. 61-62]. In a recent study, Orr re-examines Pix's use of distant geographical locations; however, she follows the conventional trend and once again overlooks The Czar of Muscovy [Orr, 2020, p. 60-61]. One of the few studies that critically examines The Czar of Muscovy is that of Jean Marsden, who labels the play a she-tragedy marked by heavy pathos [Marsden, p. 101]. In turn, Margaret Rubik denies the play any political message. She argues: "The Czar of Muscovy... reduces the history of a political uprising and the overthrow of a monarch to the level of amorous intrigue. The play is not really concerned with political but with sexual tyranny" [Rubik, p. 84].

Apparently, Rubik believes that Pix's depiction of the Russian uprising against the tyranny of Demetrius was void of any political agenda. She finds Demetrius' indulgences to be purely sexual rather than political. Suzuki Mihoko opposes Rubik's reading and believes that The Czar of Muscovy delivers a political attack against William III of England, who was king when the play was first staged. She writes that the play criticizes William's "rule by featuring an imposter, tyrant, and usurper" [Mihoko, p. 554-555]. Surprisingly, however, Mihoko's claim remains too genera, 1 as she fails to prove her point and reveal the connection between the play and William III's alleged tyranny and usurpation. These unrewarding, contradictory, and often passive readings of The Czar of Muscovy is a result of critics' inability to engage with the Russian history that shaped the play. Pix choses to dramatize a crisis in Russian history that bore strong similarities to the one that the English crown was undergoing when she wrote the play. It is argued that it was her hope that the audience would recognise the resemblances between these two historical moments and draw similar conclusions as to the illegitimacy of Dmitry and the Stuarts. The Czar of Muscovy thus assumes a didactic tone; it is clear that Pix's play was meant to edify and educate the minds of her audience on a pertinent contemporary issue that might spur them to political action. Pix's blatant disavowal of the Catholic Stuarts is thus made bare. Consequently, this paper centralises the Time of Troubles, which saw the rise and fall of the False Dmitry and connects the play to the Stuart succession crisis. Therefore, the play is received to be a political attack, not against William III, but rather against the Old Pretender, the Catholic James Francis Edward Stuart. This is done by connecting James to 
the Russian pretender. Demetrius, whom Pix undermines on both public and private levels, is thus dramatized as a figurative presentation of the Old Pretender. On a public level, Demetrius emerges as a usurper; privately, he turns out to be an effeminate tyrant.

To prove the connection between the dramatic Demetrius and the historical James, a comparison between their public characters is constructed. Significantly, both James and Demetrius share key biographical details: both are Catholic pretenders to their supposed fathers' crowns who claim their inheritance during turbulent periods in their respective contexts. To gain power, they depend on the military aid of external Catholic powers and domestic supporters. Demetrius' private life is exposed through key women: his mother, Empress Sophia; his queen, Marina Manzech; and his love, Zarriana. Through his interaction with these female characters, Demetrius proves to be both effeminate and a tyrant. In turn, the female characters stand as powerful agents and survivors who play a key role in his rise and subsequent tragic downfall. With the similar biographical details of the two pretenders firmly established, Pix invites her female audience to emulate the female Russian characters and participate in the political process in order to prevent the restoration of the Old Pretender.

\section{England and Russia's relationship between the $17^{\text {th }}$ and early $18^{\text {th }}$ centuries}

An understanding of the relationship between Russia and England makes it clear why Pix opted to dramatize Russian history rather than other popular exotic geographical locations [Orr, 2001, p. 97-134; Orr, 2020, p. 60-66]. At the time, books written about Muscovy - whether in English or in translation - generally portrayed it as a "barbarous and backward" country with an "arbitrary and tyrannical" government [Anderson, p. 144]. Emily Bartels stresses that this negative image of Russia "was vitally connected with Europe's self-image and self-authorization" [Bartels, p. 5]. Marshal T. Poe summarizes what he calls the problem of early modern Russian historiography. He writes: “...the testimony of Europeans is often viewed with grave skepticism, for it is commonly assumed that they were ignorant of Russian ways, biased against Russian manners, fooled by Russian stagecraft, or misled by their own self-serving desire to create a Russian antipode to the 'civilized' nations of Europe" [Poe, p. 5].

From the detailed plotline of The Czar of Muscovy and the deliberate manipulation of historical events, Pix reveals that she was well aware of the history of the Old Pretender's life and the events that shaped it. In the play, Russia emerges as a compassionate nation with a particular reverence for liberty and an aversion to tyranny. Pix thus departs from the dominant negative narrative about Russia found in most historical accounts. Her perspective strengthens the critical argument that the early modern antiRussian image was motivated by bias and ignorance.

Religion was another factor that played an indirect role in establishing common ground between the two countries. This common ground might 
seem odd considering the fact that Russia belonged to the Orthodox Church and England was a Protestant country. However, they were united in their perceptions of a third religion, namely Catholicism. Historically, Russian Orthodoxy had little sympathy for the Catholic Church and its Jesuits; as such, it looked at their activities with suspicion [Cross, p. 6; Anisimov, p. 15]. A famous event that confirmed the uneasy relationship between the French Catholic Church and the Orthodox Church is one that took place on 16 January 1689 when "two French Jesuits, hoping to proceed through Russia to China, were expelled" [Cross, p. 6]. During the same period, Russia issued a decree that offered the French Protestants (Huguenots) asylum [Glozier, p. 230]. The mutual understanding between Russia and England was deepened with Peter the Great's visit to London in 1698 and his friendship with William III [Cross, p. 1-15; 16-39].

In England, the 1688 Revolution deposed the Catholic James II and his presumptive heir, named James III by the Jacobites, his supporters, and the Pretender by his detractors [Pincus, p. 441-442]. James and his heir were replaced by his Protestant daughter Queen Mary II and her husband King William III, the stadtholder of Holland [Troost, p. 207-210]. William's key role in deposing the Catholics led him to be perceived as the champion of the Protestant cause [Ihalainen, p. 244]. Therefore, with Peter the Great's support for the Protestant cause in Europe, Russia was perceived as a participant in the Glorious Revolution and its outcome. Under these political circumstances and events, Pix's audience were in good stead to understand the political and religious undertones that informed The Czar of Muscovy.

\section{Comparison: False Demetrius I and the Old Pretender James Francis Edward Stuarts}

To undermine the Old Pretender, Pix showcased the false Demetrius as a complex character with both public and private sides. In the opening of the play, Demetrius declares that he is aware of the doubts surrounding his lineage. However, Demetrius I's legitimacy is not merely "doubted", as he understatedly puts it. In fact, it is proven beyond doubt that he is a usurper and imposter. His illegitimate claim to the Russian crown is confirmed by key political, religious, social, and public figures. For example, Zueski, the lord high steward of Muscovy and the closest relative to Tsar Ivan after the death of his two sons, confides to his close friend Bosman, the general of the tsar's forces,

Our good old King, left two Sons, Theodore and Demetrius, Theodore Too early paid the debt of Nature; of Fever dy'd; Demetrius by his Incle fell: Duke Boris destroy'd the growing Vertue of Demetrius in the very Bud (1.1).

Zueski explains that the dead Tsar Boris ordered the murder of the boy Demetrius, Ivan's legitimate heir, to clear his way to the throne. He thus labels the living Demetrius an "Imposter, Tyrant and usurper" (1.1). 
Zueski's confirmation of Demetrius' illegitimacy is backed by first-hand information. He informs Bosman that he himself "saw him dead, laid in the earth" (1.1) It is not only Zueski who confirms Demetrius's false identity, however. Father Fedor also stresses that Demetrius is "an exquisite and most designing Hypocrite" (1.1).

The Russians believed themselves to be the "guarantor of the Orthodox Christian ecumene" [Hosking, p. 21]. This means that despite many other contributing factors, the Orthodox Church remained a key component of Russian identity. This is most obvious in its "central role in the legitimation of secular authority. Bishops presided at official ceremonies and delivered sermons on state occasions" [Engelstein, p. 23]. Allowing the priest Fedor, a member of the Russian Orthodox Church, to deny Demetrius legitimacy is a confirmation of his status as a pretender. Empress Sophia, Demetrius' supposed mother, confesses upon seeing him, "Tis as justly feard; none, none of my Demetrius, yet as h' as been the Instrument in my Revenge on Boris, and likewise to preserve my Liberty and Life, I'll countenance the Cheat" (1.1).

Members of the Muscovite elite, namely Basilius, Zaporjus, and Rureck, also express their deep concern regarding Demetrius' legitimacy; they believe him to be a popish usurper. Rureck expresses his fear, "for much I fear he does not owe his Birth to Muscovy, I do believe, and with some reason, we have not had fair Play" (1.2). Zaporjus endorses Rureck's judgment and declares that he is uncertain of Demetrius' lineage (1.2). Basilius calls Demetrius a "suppositious Prince... [with] impostor's Arbitrary Power" (1.2). The person who emerged in 1603 as the pretender was probably Grigory: “...(or Grishka) Otrepiev, a Monk of the Miracles monastery in the Moscow Kremlin... Otrepiev fled to Poland in the Lenten Season of 1601 and there... he revealed himself as the long-lost Tsarevich. Subsequently he was Introduced at the court of King Sigismund III of Poland" [Bussow, p. XVII].

Pix not only dramatizes Demetrius as a usurper but, most importantly, as popish. The Muscovite lords are cautious of the pretender's plan "to introduce the Popes Authority, [to] the Muscovites, who bear a most implacable and deadly hate to Rome" (1.2). Pix's dramatization of Demetrius' marriage to the Polish Catholic princess Marina and the presence of her father, a general in the Polish army, can be read as confirmation of his illegitimacy and his plan to impose Catholicism on Muscovy. Pix's dramatization of the false and popish Demetrius reflects the Russian concept of the illegitimate tsar. As tsar, False Demetrius is supposed to be the protector of the Orthodox Church, yet his actions prove otherwise. His tacit acceptance of Catholicism through his marriage to a Catholic Princess and his popish affiliations confirm his illegitimacy as the Tsar of Muscovy.

When the Catholic James II was crowned king, people thought of him as a temporary ruler who would shortly be succeeded by his Anglican daughter Mary and her Protestant husband William of Orange [Daems, p. 34]. The fact that James II's queen failed to conceive a child for many years raised many suspicions when she suddenly gave birth to a healthy 
boy [Gregg, p. 53]. When James was born and baptized a Catholic, Princess Anne, James II's younger Protestant daughter, wrote a letter dated 14 March 1688 to her sister, Mary of Orange, where she expressed her suspicion of the pregnancy and suggested that it was a Catholic plot to bring an end to the Protestant succession in England [Ibid., p. 54]. Anne was not the only influential figure who suspected the birth's legitimacy. Along with influential aristocrats, the majority of the public strongly believed that the "new born child had been smuggled into the queen's bedchamber in a warming pan for hot coals" [Ibid., p. 58]. As a result of the revolution of 1688, the deposed King James II and his family escaped to France. Parliament declared the throne empty. By 1689, the Bill of Rights had written the king and his son out of succession and issued a clause that "prevents a Catholic from acceding to the throne" [Ibid., p. 35]. As a result, James Edward Stuart came to be known as a pretender. The consensus in Muscovy that considered Dmitry false echoed the English belief that James was a pretender too.

In addition to being considered pretenders by their respective contemporaries, both James and Demetrius appeared during periods of political turbulence and military conflict. Demetrius I was crowned tsar amidst political rifts. The fight over the dead tsar's throne is summarized by Basilius as follows:

Heav'n sure to ruin has destin'd our unhappy Country. Oh miserable Muscovy! Distress'd, and torn in thy own Bowels, with strong Convulsive Parties.., (1.2).

To make his point clear, Basilius draws an analogy between the factions fighting over Russia and a human body with a bowel disorder. Doctors in the early modern period believed that "all diseases went back to corrupting agents in... the stomach" [Terpstra, p. 11]. This means that to restore peace to Russia, the disparate factions needed to stop their disagreements. The conflict that caused the deterioration in Russia's health is thus of both a political and military nature. Politically, there is deep division between Demetrius' supporters and detractors. His detractors resent the bloody end of young Tsar Feodor II and his mother. Rureck clarifies that "people yet but whisper out their Greivances; shaking their Heads" (1.2). People are desperate and wish that "old Duke Boris were their Czar again" (1.2). Boris, considered a usurper, "was a wise and moderate Prince, and sought his peoples good" (1.2). These good qualities are not displayed by Demetrius. The contrast between Boris the good ruler-usurper and Demetrius the tyrant - legitimate Tsar confuses the Muscovites. This confusion means that Demetrius' position is not secure. Noticing Demetrius' infatuation with Zarriana, Fedor reminds him of his precarious position:

Think, Sir, on what you do, and recollect yourself e'er too late;

You're ruin'd else, you are not well seteld in your Throne, and one false Step will throw you out again (1.2). 
What makes Demetrius' position so precarious is the presence of Lord Zueski. Basilius argues, "we have a Prince, whose Vertues well deserve the Grandieur of a Crown, bring next in Blood to great Basilovitz" (1.2).

Like Demetrius, Prince James appeared in the middle of a political and military conflict. His father's authority as king had been challenged by two rebellions; the first of which was led by his nephew and King Charles II's eldest illegitimate son, James Scott, the duke of Monmouth [The London Gazette, p. 2]. In the same year, a second rebellion was led by the earl of Argyll in Scotland. Argyll failed and was arrested and beheaded on 18 June 1685 [Harris, p. 75-76]. Besides these contestations over the English crown, the era was marked by conflict between the king and Parliament over the Catholic cause in England [Miller, p. 142-143, 164-167]. Like the Muscovites, the Protestant English resented the presence of Jesuits in London [Harris, p. 258-259]. The Protestant population was wary of the growing power and presence of Catholicism [Miller, p. 127-128; Harris, p. 269-272]. Unable to accept a Catholic pretender on the English throne, powerful aristocrats decided to replace James II and his pretender heir with the Protestant Mary, married to William of Orange. As the daughter of James II, Mary's lineage was a perfect replacement for her father and supposed brother. Mary can be seen as the dramatic counterpart to Lord Zueski, whose well-known birth and virtues qualified him to replace the pretender Demetrius. The English invited Mary and William III to invade England with an army [Ashley, p. 201-202]. Pix's principal lords of Muscovy act in a similar manner when they plan to replace Demetrius with the legitimate Zueski.

To strengthen their claims to the respective crowns, both the English and the Russian pretenders use military measures that depend on external Catholic powers and domestic supporters. To sit on the Russian throne, Demetrius enlists the military help of the Catholic Polish king and the voevoda of Sendimira. Zueski reminds Bosman that the "Vaivode of Sendimira and the Polish King have set him up: More I need not tell you" (1.1). In addition to foreign help, Demetrius also enjoys the support of his domestic followers. Zueski tells Bosman that "MoSco ... open'd wide her Gates to welcome him" (1.1). Demetrius boasts about his ability to secure the support of both Catholic Poles and Russian Orthodox Cossacks. He preens to the disenchanted Fedor, who warns him against his precarious position: "Thou see'st not with thy Coward Eyes the intricate Designs of State: Can I secure the Poles and Cossacks, faithful to my Services?" (2.2).

In turn, the English pretender resorted to a similar strategy and enlisted the help of the Catholic Louis XIV of France to secure his claim. One must keep in mind that the Old Pretender's attempts to regain the throne took place before and after the staging of The Czar of Muscovy in 1701. After 1701, the pretender himself approached Louis XIV for support; before that, it had been done by his father James II. James II tried to regain the throne not only for himself but for his son as well; he invaded England in 1689 with the assistance of French troops [Miller, p. 222-233]. In addition to external help, James was aided by domestic supporters, who came to be 
known in history as the Jacobites. The Jacobites were a mix of Catholics and Protestants who fought to restore James and the Old Pretender to the English throne [Lenman, p. 36; O'Ciardha, p. 21, 30].

The affinities shared by the English and Russian pretenders go deeper than biographical details, however. A notable similarity is found in their political impacts on their immediate environments and Europe at large. Historically, both pretenders were part of a larger political game wherein Catholicism aggressively sought to consolidate its position as an influential geopolitical power in Europe. In turn, the Protestant English and the Orthodox Russians fiercely resisted Catholicism. During the Time of Troubles in Russia, the Catholic Polish King Sigismund III Vasa (15871632) considered the false Dmitry to have the promising ability to control Russia [Platonov, p. 45-84]. To that end, the king and his Jesuits supported Dmitry's false claim to the Russian throne [Dunning, p. 135]. In order to secure the Polish king's support and install him as the tsar, Dmitry "became a convert to Roman Catholicism" [Bussow, p. XVII]. Furthermore, in 1605, he decided to marry the "Polish Catholic princess, Marina Mniszech the daughter of his... military commander, Jerzy Mniszech, the Palatine of Sandomierz" [Dunning, p. 214; Bussow, p. XVII]. The Orthodox Church opposed the marriage and "demanded that Marina convert to Orthodoxy before the wedding. The request was rejected by Maria who insisted on remaining a Catholic, and the Tsar [Demetrius] backed her up" [Dunning, p. 214]. His complacent attitude towards his bride's faith along with his decision to allow Catholics - and even Jesuits - into his court supported the view that he was a mere tool used to "destroy the Russian Orthodox Church" [Ibid., p. 213].

England's situation was not very different from that of Russia. Like King Sigismund of Poland, Louis XIV supported the Catholic Stuarts. Louis needed a Catholic ally in England to support him in his territorial expansion and claim to the Spanish crown [Nolan, p. 116; Lynn, p. 191256]. The similar biographical, historical, and ideological milieus of both pretenders proved most useful to Pix's dramatization.

\section{Demetrius' tyranny and effeminacy}

Pix's female audience was at the core of her dramatic enterprise. To entice the female audience into anti-pretender sentiments, Pix adopts two techniques that depended on warning the audience against the restoration of the English pretender. She invites them to emulate the Russians and bring an end to the Pretender's political aspirations. To execute her strategy, she employs a complex dramatic process. Demetrius is exposed on a private level as both a tyrant and an effeminate man. This exposure is done through female characters. Who play a key role in his rise to power and subsequent fall. Pix was a typical Whig in that she was against the Catholic Stuarts and supported "active resistance against tyranny" [Cuder-Dominguez, p. 85]. In reference to his private life, Pix focuses on the female characters who shaped Demetrius' life. This mode of dramatization enables Pix 
to take a non-political stand while turning tyranny and effeminacy into purely moral issues. The female characters include Queen Marina, Empress Sophia, and Zarriana. Demetrius' tyranny is exposed through his treatment of these women.

Demetrius marries the heartbroken Marina for political gains. After the marriage ceremonies, he mentions his supporters, the lords of Muscovites, and his father-in-law, but makes no reference to Marina. This is early evidence of Marina's insignificant presence in her husband's life. She appears to be nothing more than an object he uses in order to gain the throne. This attitude is in complete harmony with the system of patriarchy, which promotes male privilege and female oppression [Johnson, p. 5]. "The Second Sex, Simone de Beauvoir writes that according to the patriarchal concept, a woman "is the incidental, the inessential as opposed to the essential. [Man] is the Subject, he is the Absolute - she is the Other" [Beauvoir, p. 26]. To stress his absolute tyranny, Demetrius refuses to consummate his marriage to Marina and seeks divorce. He orders Fedor:

Be gone, I say without Reply, and do as I command you; and Let the Empress know, either she must resolve quietly to retire where I wou'd have her; or I shall not want Pretence of taking off her Head (2.2).

Demetrius makes it clear that he wants Marina out of his life without delay. Their marriage enables him to become the tsar of Russia, but after securing the crown, Marina ceases to be of any use to him. He threatens her with death should she refuse to comply with his order, which is to resign her title and accept the divorce. Unfazed by his threats, Marina labels him as a tyrant: "Now, Sir, indeed you do appear yourself, a faith-less Husband and lawless Tyrant" (3.1).

His ruthless tyranny is traced back to his treatment of his supposed mother, Empress Sophia. To secure the crown, he treats the old empress with reverence and respect, only to later plan her murder. Sophia makes it clear that she needs him "to preserve [her] Liberty and Life" (1.1). Her fear for her life and liberty confirms Demetrius' tyranny. True to his reputation, he orders that Bosman "rid me of my curst Domestick Plagues; Sophia and Marina by poy-son, or any other Secret way" (4.2). Demetrius proves that his treatment of those he loves is no different from those he considers to be a "domestic plague". Zarriana, with whom he falls in love at first sight, is subjected to horrendous tyranny. Before they meet, Demetrius has already murdered her brother, the tsar, and her mother. He separates her from Zueski, the man she loves and promised to marry, orders his death, and attempts to rape her.

Determined to keep Zarriana for himself, he prevents her from meeting Zueski. When he discovers them together, he orders the guards, "away with him, and see his Head struck off immediately" (2.2). On her knees, she begs for Zueski's life. Addressing Demetrius, "Oh, royal Sir, pity a miserable Maid, to beg for him a pardon, is the only good my wretched 
Fortune let me" (2.2). Untouched by her pleads, he responds: "Unwise Zarrianna, to think I'll hear thy pleadings for my rival; thy fondness of him does but urge his Fate Haste" (2.1). To Zarriana, the ordered killing of her love is the ultimate act of tyranny. She reminds him of his previous bloody act against her family:

Hand... of Hell... always guides thy Heart, Pernicious Tyrant. Was't not enough your Cruelty depriv'd me of my parents and Brother...

but to compleat my Miseries, and

make me truly wretched, thou'st rob'd me of a Husband (2.2).

Refusing to return his love, Demetrius longs for "a brave Revenge." He declares his revenge is to "force Zarriana to my last Embraces, and see expiring by my side" (5.1).

Demetrius proves to not only be tyrannical but effeminate as well. However, before a discussion of Demetrius' effeminacy, one first needs to understand the meaning of the term and its implications during Pix's era. Susan Owen explains that during the Restoration era and the early eighteenth century, effeminacy came to mean a "sense of excessive preoccupation with women and love" [Owen, 2002, p. 161]. She also explains that during the Restoration, it referred to political irresponsibility and incompetence [Owen, 1996, p. 9; Owen, 2002, p. 161]. The Stuart brothers, Charles II and James II, were considered by their contemporaries to be effeminate [Ibid., p. 201]. In her dramatization of Demetrius' effeminacy, Pix makes sure that it aligns with the Restoration's conceptualisation of the word. Demetrius confesses, “Tis Said I am not Master of my Passion” (3.1). He also confirms, "No Laws I'll own, but what to Pleasure tends" (2.2). His lack of self-control and willingness to abide by the law are traits that are firmly associated with effeminacy [Edwards, p. 91]. Indeed, from the beginning, Demetrius emerges as a man enslaved to his passions and sexual desires. Immediately after his marriage to Marina and before consummating the marriage, he becomes infatuated with Zarriana. Upon seeing her, he praises her beauty: "this is a Pearl too precious for the Store of one, who does not understand the Value" (1.1). Unfazed by the fact that Zarriana is engaged to marry Zueski, he informs her, "I'll find the way to make thee change the Object of thy foolish Vows" (1.1). He complains to his faithful Carclos, "She is so proud, that she con-temns and scorn me, as if I were the meanest of her Slaves" (3.1). Facing her strong rejection of his passion, he simply tells her, "tis not possible that I can live with-out thee" (2.2). To tempt her into forgetting Zueski's love and accept his, he promises to "set [her] upon the Russian throne" (2.2). Indeed, Demetrius is so obsessed with Zarriana that he loses his political judgment. His advisor Fedor thus warns him more than once of the destructive consequences of his infatuation: "this Act you are about to do will ruin you...' $\mathrm{t}$ ' will cost thy Crown and Life" (2.2). Determined to follow his passion, Demetrius insists, "this Fair one I must and will enjoy, tho' I shou'd lose my Kingdom in pursuit of her" (1.1). 


\section{Demetrius' road to power and downfall}

In addition to exposing Demetrius' tyranny and effeminacy, the female characters play a key role in his rise to power and subsequent tragic downfall. Marina reminds him that annulling their marriage will cost him the crown. Marina condemns him: "Ungrateful Prince, you know his Succours plac'd you in your Throne, gave you by his Assistance the Power you now wou'd use for his Destruction" (3.1). A key character that further helped him become the tsar of Russia is Empress Sophia, his supposed mother. She confirms his claim as her long-lost son Demetrius and welcomes him: "My dearest Son preserv'd by Heav'n to know a better Fortune than what thy inhumane Uncle destin'd for thee, come to my Arms, and take a Mother's Blessing" (1.1).

Significantly, however, these women not only help him gain power, but also bring about his downfall. Marina warns him: "I have a father, who dares and will revenge my Wrongs" (3.1). Indeed, Manzeck promises to avenge his daughter and dethrone Demetrius. He joins the rebellious Muscovites and informs Bosman, "My Forces are already drawn into a Body; and when you give the Word, I'll at their Head appear, and order them where-ever you appoint" (3.2). Another key role is played by Sophia. Full of regrets, she acknowledges her mistake in confirming him to be her son. She confesses, "My Women's Fears betray'd me to own this base Imposter for my son... Better I had dy'd to save my ruin'd Country, which now grieves under his oppressing Yoak" (4.2). In turn, Zarriana plays an indirect role in empowering and destroying Demetrius. Early in the play, Zueski, aware of Demetrius' fake identity, refrains from exposing him to save Zarriana's life. He "humbly bow[s] to beg the life of Zarriana... Daughter of the late Duke Boris" (1.1). Zueski promises Bosman he will destroy Demetrius: "But here I swear, by all the Holy Saint, I will not lose her thus; and if no honest Hand and Heart will help me; I'll boldly do't smy self" (1.1).

One must keep in mind that unlike Demetrius, who proves to be true to his historical counterpart, Pix's powerful female characters are not. Zarriana, who is Tsar Boris' daughter in the narrative, is only loosely based on historical details. Natalia Pushkareva writes that the Tsarevna Ksenia Borisovna Godunova's "beauty became legendary." Besides being beautiful, she "was intelligent... [and] preferred the effort of study to the boredom of inactivity... She became skilled at the writing" [Pushkareva, p. 78-79]. Tragically, she was raped by false Dmitry, who kept her as his concubine for five months until his marriage to Marina Mniszech [Julicher, 2003, p. 33]. She was subsequently forced to take monastic vows, given the name Olga, and sent to the Voskresensky Monastery in Beloozero [Ibid., p. 319]. The historical details of Ksenia's tragic life allows one to perceive the distance between her and her dramatic counterpart Zarriana. Unlike the victimised and silenced historical Ksenia, Zarriana emerges as a powerful woman with a strong voice. Pix allows her beauty to be an effective weapon that exposes Demetrius' negative qualities, avoids rape, and brings about his downfall. 
The historical figure of Marina Mniszech was not the sentimental and idealised character that Pix dramatizes. She was considered instrumental in the Polish scheme to control Russia during the Time of Troubles. She was resented by the Russians to such an extent that she was often referred to as Marinka the Witch [Ivanits, p. 88]. After the death of her husband Dmitry in 1606, she married another imposter, who was killed in 1610 [Dunning, p. 410-440]. After a failed attempt to install her son Ivan, whom she claimed to be Dmitry's heir, she was arrested by Mikhail Romanov. Her son was executed, and she was placed in a prison until the end of her life [Ibid., p. 443]. The Russian poet Alexander Pushkin, who dramatized Marina's life in his play Boris Godunov (1825), describes her as having "only one passion and that was ambition" [Dunning, p. 96-97]. The historically ruthless and destructively ambitious Marina is thus replaced by a gentle, selfless, and utterly unambitious dramatic persona.

Like Marina, the dramatic Sophia also has little in common with her historical counterpart Maria Nagaya (1553-1608), the widow of Ivan the Terrible and the mother of the real Dmitry (1581-1591), who died as a boy [Julicher, p. 23-24]. Historically, Maria married Ivan IV in 1581 and gave birth to their son Dmitry in 1582. Being the tsar's seventh wife, she did not have any political power, as the Church did not recognize any marriage beyond the third wife. With this status, her son "was not eligible to become tsar" [Julicher, p. 23]. Despite this, Marina believed "her son to be the legitimate tsarvich" [Ibid., p. 23]. When her son died due to an epileptic seizure, she blamed Tsar Boris. Motivated by anger and the desire for revenge, she supported the false Dmitry's claim that he was her son [Ibid., p. 24-25]. Significantly, Pix dramatizes Sophia [Maria] as an unambitious figure mainly concerned with her safety and that of the country.

Critics have hitherto failed to appreciate Pix's manipulation of historical characters whom she turned into powerful dramatic agents. For example, Jean Marsden argues that Pix did not stray from the male literary establishment with its patriarchal order [Marsden, p. 101]. Derek Hughes condemns Pix for her lack of an independent voice as she "distinguished herself as a slavish upholder of male authority" [Hughes, p. 419]. This dramatic misreading is the result of two factors: first, there is an inability to see beyond the play's intense sense of pathos; second, critics overlook the historical dimensions of the characters and the distances that separate them from Pix's dramatic personas. True enough, Pix's female characters experience a fair amount of emotional distress; however, unlike the typical characters of a she-tragedy, they retain their dignity, challenge male tyranny, and emerge victorious.

Pix's novel approach to female dramatic personas enables her to avoid the tragic traps of their historical fates and stage them as powerful and inspirational women who emerge victorious against all the odds. In doing so, Pix connected the female Russian characters with their real-world English counterparts, an essential step towards encouraging the latter to take an anti-pretender stand. This approach seems rather independent 
from the real patriarchal world outside the theatre. However, when Pix was writing plays, women had a public voice both on and off the stage. Paula Backscheider argues that the early 1690s witnessed "unprecedented debate and discussion about the nature and place of women" [Backscheider, p. 72]. Queen Mary II, who reigned between 1689 and 1694, was a good example of a loud female voice in a patriarchal context. She was presented as an ideal queen who combined "Female Sweetness" with "Courage Masculine" [Park, p. 4]. In spite of her love for her father James II, she opposed him, took a stand against the Pretender, and accepted the English crown as a necessary step in order to save "the Church and State" [Kiste, p. 95]. Away from the political arena, women's search for a voice became a feature on the social scene during Pix's time. Mary Astell (1666-1731) was a well-known writer of the era who was concerned with the empowerment of women through education [Broad, 2015, p. 3]. She wrote Serious Proposal to the Ladies (part I in 1694 and part II in 1697), where she "urged her readers to abandon their frivolous pursuits, and, instead, to devote their time to improving their mind" [Smith, p. 31]. To Astell, education enables women to obtain a sense of self-worth and, consequently, the power to survive in patriarchal domains [Ibid., p. 31-32]. Pix's era was thus marked by women as a mobilizing rather than passive force [Backscheider, p. 72]. This reveals that: "...interest in women had never been greater, they had become an increasingly significant group of 'culture consumers.' Their contemporaries saw them as an important part of the theatre audience and believed that they had began to have considerable influence" [Ibid., p. 72].

Writing in this context, it was not difficult for Pix to address her female audience and invite them to follow the female Russian dramatic personas. The female audience could thus understand Pix's message to play their part in preventing the restoration of the English Catholic Pretender James.

Since its first performance, the critical fate of Mary Pix's The Czar of Muscovy has lain between marginalization and misinterpretation. This paper is an attempt to re-read the play as a dramatic experience firmly connected to a period plagued by political conflict, wherein the Stuart succession crisis assumed centre stage. A key factor in this reading is the Russian history of the Time of Troubles and the Orthodox Church's hostility towards Catholicism. The play's Russian affiliation proves a key factor in determining the play's meaning and underlying political and ideological message. The argument stresses that the play is a political attack against James Francis Edward Stuart and not William III, as claimed by Mihoko. Pix undermines the Old Pretender's claim to the English throne and warns her audience against his restoration by connecting him to the false Dmitry. Demetrius, whom Pix criticises on both public and private levels, is dramatized as a figurative representation of the Pretender James. On the public level, Demetrius emerges as a pretender while he is privately 
an effeminate tyrant. To confirm the affinities between both pretenders, a comparison between their public characters is constructed. Pointedly, both share similar biographical details.

Generally speaking, Pix remained faithful to the historical narrative of the false Dmitry This was a crucial step in not only undermining James, but also manipulating the audience into being active participants in preventing his restoration. Pix thus sends an indirect message to her audience. The message indicates that since both pretenders share significant affinities, there is the possibility of a similar end. This approach is further strengthened through her exposure of Demetrius' tyranny and effeminacy. It is essential to keep in mind that these qualities were long connected with James II, Charles II, and Charles I. Significantly, she showcases Demetrius' private side to avoid the ideological and dramatic trap of being too obvious about her anti-pretender sentiments. She achieved this by pushing the pretender narrative to the background and instead focused on false Demetrius' negative aspects, thus allowing the audience to make the logical connection.

Another factor that distinguishes Pix's dramatization of Demetrius' private side is the involvement of key female characters in his life; Marina, Sophia, and Zarriana. One should keep in mind that Pix subjects them to extensive revision, as she avoids their tragic fates and turns them into powerful agents who face Demetrius' oppression effectively. Furthermore, she allows them to play a key role in Demetrius' rise to power and his tragic fall. By centralizing the female characters in the political game, she sends indirect signals to her female audience to follow the Russian female characters and prevent the restoration of the pretender James. The engagement of her female audience allows her to unite society against Stuart Catholicism in general and the Old Pretender in particular. Therefore, Pix turns Russian history into a compelling feature not only in The Czar of Muscovy but also in the English succession crisis.

Most of the written history about Russia during the seventeenth century was damning. Pix manages to break the mould and showcases an independent approach with deep knowledge of Russian history. Her task was facilitated by the recent visit of Peter the Great to London and his support of Protestantism in the face of Catholic France. She anchored the English succession crisis in the Russian the Time of Troubles, wherein similar problems were experienced. She thus gave her own perspective on the future of the English and the way to preserve their liberties. Significantly, through her female characters and the role they play in the political game, she acknowledges the growing voice of women in her era. Through the female Russian characters who empower and destroy Demetrius, she invites the women of her time to participate in protecting their liberties. Therefore, Russian history emerges with a double task; it unites the men and women of England in one cause and helps them prevent the restoration of James Francis Edward, the Catholic Pretender. 


\section{Список литературы}

Anderson M. S. Peter the Great. L. : Routledge, 2014. 244 p.

Anisimov E. The Reforms of Peter the Great : Progress through Coercion in Russia. L. : Routledge, 2015. 344 p.

Ashley M. The Glorious Revolution of 1688. L. : Hodder and Stoughton, 1966. 224 p.

Backscheider P. Spectacular Politics: Theatrical Power and Mass Culture in Early

Modern England. Baltimore : John Hopkins Univ. Press, 1993. 360 p.

$234 \mathrm{p}$.

Bartels E. Spectacles of Strangeness. Philadelphia : Pennsylvania Univ. Press, 1993.

Beauvoir S. The Second Sex. L. : Penguin, 1972. 880 p.

Broad J. The Philosophy of Mary Astell: An Early Modern Theory of Virtue. Oxford :

Oxford Univ. Press, 2015. 205 p.

Bussow C. The Disturbed State of the Russian Realm, 1617. Montreal : McGill-Queen's

Univ. Press, 1994. 288 p.

Cross A. Peter the Great through British Eyes: Perception and Representation of the Tsar since 1698. Cambridge : Cambridge Univ. Press, 2000. 172 p.

Cuder-Domingez P. Stuart Women Playwrights, 1613-1713. L. : Ashgate, 2016. 158 p.

Daems J. Seventeenth Century Literature and Culture. L. : Continuum, 2006. 160 p.

Dunning Ch. Russia First Civil War: The Time of Trouble and the Founding of the

Romanov Dynasty. Pennsylvania : Pennsylvania State Univ. Press, 2001. 672 p.

$E d w a r d s C$. The Politics of Immorality in Ancient Rome. Cambridge : Cambridge Univ.

Press, 1993. 244 p.

Engelstein L. Old and Low: Straw Horsemen of Russian Orthodoxy // Orthodox Russia:

Belief and Practice under the Tsars / ed. by V. A. Kivelson, R. H. Greene. Pennsylvania :

Pennsylvania State Univ. Press, 2003. P. 23-32.

Finberg M. C. Introduction in Eighteenth-century Women Dramatists. Oxford : Oxford Univ. Press, 2008. 448 p.

Finke L. The Satire of Women Writers: The Female Wits // Restoration. Vol. 8. 1984.

No. 2. P. 64-71.

Glozier M. Huguenot Soldiers in Russia: A Study in Military Competence // War,

Religion and Service Huguenot Soldiering, 1685-1713 / ed. by M. Glozier, D. Onnekink.

L. : Routledge, 2007. P. 229-244.

Gregg E. Queen Anne. New Haven : Yale Univ. Press, 2001. 483 p.

Haight $R$. Christian Community in History : Historical Ecclesiology. N. Y. : Continuum, 2004. $464 \mathrm{p}$.

Harris T. The Revolution: The Great Crisis of the English Monarchy, 1685-1720. L. : Penguin, 2006. $622 \mathrm{p}$.

Hensbergen $C$. $V$. The Female Wits: Gender, Satire, Satire and Drama // The Oxford

Handbook of Eighteenth-century Satire / ed. by P. Bullard. Oxford : Oxford Univ. Press, 2019. P. 74-90.

Hosking $G$. The State and Identity Formation in Russia: Historical Account // The Concept of Russia Pattern for Political Development in Russian Federation / ed. by F. Scharpe, K. Malfliet. Leuven : Leuven Univ. Press, 2003. P. 21-34.

Hughes D. English Drama, 1660-1700. Oxford : Clarendon Press, 1996. 520 p.

Ihalainen P. Protestant Nations Redefined: Changing Perceptions of National Identity in the Rhetoric of the English, Dutch and Swedish Public Churches, 1685-1772. Leiden : Brill, 2005. $664 \mathrm{p}$.

Ivanits L. Russian Folk Belief. L. : Routledge, 1992. 272 p.

Johnson A. The Gender Knot: Unravelling our Patriarchal Legacy. Delhi : Pearson Ed., 2005. $322 \mathrm{p}$.

Julicher P. Renegades, Rebels and Rogues under the Tsars. L. : McFarland and Company Publ., 2003. 318 p.

Kiste V. D. William and Mary: Heroes of the Glorious Revolution. Stroud : Sutton Publ., 2008. $288 \mathrm{p}$. 
Lenman B. The Jacobite Risings in Britain 1689-1746. Methuen : Methuen Publ., 1980. $320 \mathrm{p}$.

Lynn J. The Wars of Louis XIV, 1667-1714. L. : Routledge, 2013. 421 p.

Marsden J. Fatal Desires: Women, Sexuality and the English Stage, 1660-1720. L. : Cornell Univ. Press, 2006. 232 p.

Mihoko S. Recognizing Women's Dramas as Political Writings: The Plays of 1701 by Wiseman, Pix and Trotter // Women's Writing. 2011. Vol. 18. No. 4. P. 547-564.

Miller J. James II. New Haven : Yale Univ. Press, 2000. 304 p.

Nolan C. The Allure of Battle: A History of How Wars have been Won and Lost. Oxford : Oxford Univ. Press, 2017. 728 p.

O'Ciardha E. Ireland and the Jacobite Cause, 1685-1766. Dublin : Four Courts, 2002. $468 \mathrm{p}$.

Orr B. Empire on the English Stage. Cambridge : Cambridge Univ. Press, 2001. 350 p.

Orr B. British Enlightenment Theatre: Dramatizing Differences. Cambridge : Cambridge Univ. Press, 2020. 285 p.

Owen S. Restoration Theatre in Crisis. Oxford : Clarendon Press, 1996. 343 p.

Owen S. Perspective on Restoration Drama. Manchester : Univ. of Manchester Press, 2002. 208 p.

Park H. Lachryme Sacerdotis: A Pindarick Poem Occasion'd by the Death of that Most Excellent Princess, our Late Gracious Sovereign Lady, Mary the Second, of Glorious Memory. L. : John Dunton, 1695. 8 p. $664 \mathrm{p}$.

Pincus S. 1688: The First Modern Revolution. New Haven : Yale Univ. Press, 2011.

Platonov S. The Time of Troubles : A Historical Study of the Internal Crisis and Social Struggle in the Sixteenth and Seventeenth-century Muscovy. Kansas : Univ. of Kansas, $1985.216 \mathrm{p}$.

Poe M. T. A People Born to Slavery: Russia in Early Modern European Ethnography, 1476-1748. Ithaca : Cornwell Univ. Press, 2018. 312 p.

Pushkareva N. Women in Russian History: From the Tenth to the Twentieth Century. L. : Routledge, 2015. 300 p.

Rubik M. Early Women Dramatist, 1550-1800. L. : MacMillan, 1998. 225 p.

Smith H. Mary Astell, A Serious Proposal to the Ladies (1694), and Anglican Reformation of Mannerism in Late Seventeenth-Century England // Mary Astell: Reason, Gender, Faith / ed. by W. Kolbrener, M. Michelson. L. : Routledge, 2007. P. 31-48.

Terpstra N. Lives Uncovered: A Sourcebook of Early Modern Europe. Toronto : Univ. of Toronto Press, 2019. 304 p.

The London Gazette. 1685. No. 2051. 13 July.

Troost W. William III: The Stadholder-King: A Political Biography. L. : Routledge, 2017. $380 \mathrm{p}$.

Yebra J. M. The Flourishing of Female Playwriting on the Augustan Stage: Mary Pix's The Innocent Mistress // J. of English Studies. 2014. Vol. 12. P. 149-167.

\section{References}

Anderson, M. S. (2014). Peter the Great. L., Routledge. 244 p.

Anisimov, E. (2015). The Reforms of Peter the Great: Progress through Coercion in Russia. L., Routledge. 344 p.

Ashley, M. (1966). The Glorious Revolution of 1688. L., Hodder and Stoughton. 224 p. Backscheider, P. (1993). Spectacular Politics: Theatrical Power and Mass Culture in Early Modern England. Baltimore, John Hopkins Univ. Press. 360 p. $234 \mathrm{p}$.

Bartels, E. (1993). Spectacles of Strangeness. Philadelphia, Pennsylvania Univ. Press.

Beauvoir, S. (1972). The Second Sex. L., Penguin. 880 p.

Broad, J. (2015). The Philosophy of Mary Astell: An Early Modern Theory of Virtue. Oxford, Oxford Univ. Press. 205 p. 
Bussow, C. (1994). The Disturbed State of the Russian Realm, 1617. Montreal, McGillQueen's Univ. Press. 288 p.

Cross, A. (2000). Peter the Great through British Eyes: Perception and Representation of the Tsar since 1698. Cambridge, Cambridge Univ. Press. $172 \mathrm{p}$.

Cuder-Domingez, P. (2016). Stuart Women Playwrights, 1613-1713. L., Ashgate. 158 p.

Daems, J. (2006). Seventeenth Century Literature and Culture. L., Continuum. 160 p.

Dunning, Ch. (2001). Russia First Civil War: The Time of Trouble and the Founding of the Romanov Dynasty. Pennsylvania, Pennsylvania State Univ. Press. 672 p.

Edwards, C. (1993). The Politics of Immorality in Ancient Rome. Cambridge, Cambridge Univ. Press. 244 p.

Engelstein, L. (2003). Old and Low: Straw Horsemen of Russian Orthodoxy. In Kivelson, V. A., Greene, R. H. (Eds.). Orthodox Russia: Belief and Practice under the Tsars. Pennsylvania, Pennsylvania State Univ. Press, pp. 23-32.

Finberg, M. C. (2008). Introduction in Eighteenth-century Women Dramatists. Oxford, Oxford Univ. Press. 448 p.

Finke, L. (1984). The Satire of Women Writers: The Female Wits. In Restoration. Vol. 8. No. 2, pp. 64-71.

Glozier, M. (2007). Huguenot Soldiers in Russia: A Study in Military Competence. In Glozier, M., Onnekink, D. (Eds.). War, Religion and Service Huguenot Soldiering, 16851713. L., Routledge, pp. 229-244.

Gregg, E. (2001). Queen Anne. N. Haven, Yale Univ. Press. 483 p.

Haight, R. (2004). Christian Community in History: Historical Ecclesiology. N. Y., Continuum. 464 p.

Harris, T. (2006). The Revolution: The Great Crisis of the English Monarchy, 16851720. L., Penguin. $622 \mathrm{p}$.

Hensbergen, C. V. (2019). The Female Wits: Gender, Satire, Satire and Drama. In Bullard, P. (Ed.). The Oxford Handbook of Eighteenth-century Satire. Oxford, Oxford Univ. Press, pp. 74-90.

Hosking, G. (2003). The State and Identity Formation in Russia: Historical Account. In Scharpe, F., Malfliet, K. (Eds.). The Concept of Russia Pattern for Political Development in Russian Federation. Leuven, Leuven Univ. Press, pp. 21-34.

Hughes, D. (1996). English Drama, 1660-1700. Oxford, Clarendon Press. 520 p.

Ihalainen, P. (2005). Protestant Nations Redefined: Changing Perceptions of National Identity in the Rhetoric of the English, Dutch and Swedish Public Churches, 1685-1772. Leiden, Brill. $664 \mathrm{p}$.

Ivanits, L. (1992). Russian Folk Belief. L., Routledge. 272 p.

Johnson, A. (2005). The Gender Knot: Unravelling our Patriarchal Legacy. Delhi, Pearson Ed.. 322 p.

Julicher, P. (2003). Renegades, Rebels and Rogues under the Tsars. L., McFarland and Company Publ. $318 \mathrm{p}$.

Kiste, V. D. (2008). William and Mary: Heroes of the Glorious Revolution. Stroud, Sutton Publ. 288 p.

Lenman, B. (1980). The Jacobite Risings in Britain 1689-1746. Methuen, Methuen Publ. 320 p.

Lynn, J. (2013). The Wars of Louis XIV, 1667-1714. L., Routledge. 421 p.

Marsden, J. (2006). Fatal Desires: Women, Sexuality and the English Stage, 16601720. L., Cornell Univ. Press. 232 p.

Mihoko, S. (2011). Recognizing Women's Dramas as Political Writings: The Plays of 1701 by Wiseman, Pix and Trotter. In Women's Writing. Vol. 18. No. 4, pp. 547-564.

Miller, J. (2000). James II. New Haven, Yale Univ. Press. 304 p.

Nolan, C. (2017). The Allure of Battle: A History of How Wars have been Won and Lost. Oxford, Oxford Univ. Press. 728 p.

O'Ciardha, E. (2002). Ireland and the Jacobite Cause, 1685-1766. Dublin, Four Courts. 468 p.

Orr, B. (2001). Empire on the English Stage. Cambridge, Cambridge Univ. Press. 350 p. 
Orr, B. (2020). British Enlightenment Theatre: Dramatizing Differences. Cambridge, Cambridge Univ. Press. 285 p.

Owen, S. (1996). Restoration Theatre in Crisis. Oxford, Clarendon Press. 343 p.

Owen, S. (2002). Perspective on Restoration Drama. Manchester, Univ. of Manchester Press. 208 p.

Park, H. (1695). Lachryme Sacerdotis: A Pindarick Poem Occasion'd by the Death of that Most Excellent Princess, our Late Gracious Sovereign Lady, Mary the Second, of Glorious Memory. L., John Dunton. 8 p. $664 \mathrm{p}$.

Pincus, S. (2011). 1688: The First Modern Revolution. New Haven, Yale Univ. Press.

Platonov, S. (1985). The Time of Troubles: A Historical Study of the Internal Crisis and Social Struggle in the Sixteenth and Seventeenth-century Muscovy. Kansas, Univ. of Kansas. 216 p.

Poe, M. T. (2018). A People Born to Slavery: Russia in Early Modern European Ethnography, 1476-1748. Ithaca, Cornwell Univ. Press. 312 p.

Pushkareva, N. (2015). Women in Russian History: From the Tenth to the Twentieth Century. L., Routledge. 300 p.

Rubik, M. (1998). Early Women Dramatist, 1550-1800. L., MacMillan. 225 p.

Smith, H. (2007). Mary Astell, A Serious Proposal to the Ladies (1694), and Anglican Reformation of Mannerism in Late Seventeenth-Century England. In Kolbrener, W., Michelson, M. (Eds.). Mary Astell: Reason, Gender, Faith. L., Routledge, pp. 31-48.

Terpstra, N. (2019). Lives Uncovered: A Sourcebook of Early Modern Europe. Toronto, Univ. of Toronto Press. 304 p.

The London Gazette. (1685). No. 2051. 13 July.

Troost, W. (2017). William III: The Stadholder-King: A Political Biography. L., Routledge. 380 p.

Yebra, J. M. (2014). The Flourishing of Female Playwriting on the Augustan Stage: Mary Pix's The Innocent Mistress. In J. of English Studies. Vol. 12, pp. 149-167.

The article was submitted on 11.08.2020 